
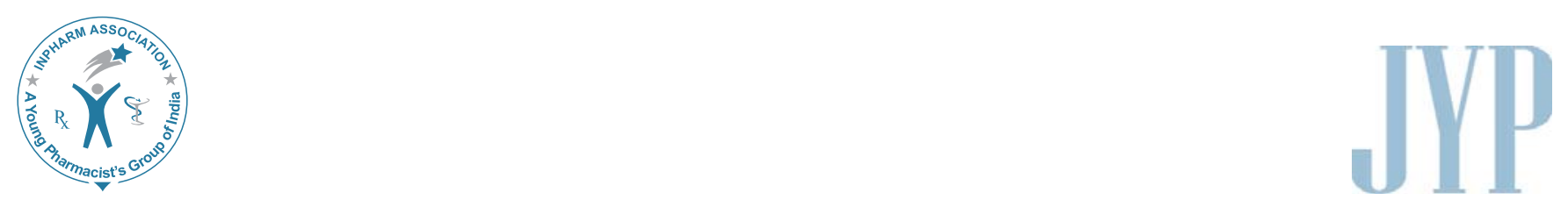

\title{
Studies on the Anthelmintic Property of Aminobenzylated Mannich Bases
}

\author{
Chaluvaraju KC, Bhat KI \\ Department of Pharmaceutical Chemistry, Government College of Pharmacy, Bangalore, India \\ Address for correspondence: Dr. K. C. Chaluvaraju; E-mail: chaluvarajukc@gmail.com
}

\begin{abstract}
Studies were conducted on the anthelmintic property of about $15(\mathrm{e}-\mathrm{h}, 1 \mathrm{e}-1 \mathrm{~h}, 2 \mathrm{~d}-2 \mathrm{f}$ and $3 \mathrm{e}-3 \mathrm{~h})$ synthesized aminobenzylated Mannich bases bearing N-methyl piperazine using Indian earthworms Pheritima posthuma against piperazine citrate as standard reference. Three concentrations of each compound $(0.1,0.2,0.3 \% \mathrm{w} / \mathrm{v})$ were studied, which involved the determination of paralysis and death time of the worms. The compound $1 \mathrm{~g}$ exhibited the most significant anthelmintic activity among all the compounds screened against the worms as compared to standard drug.
\end{abstract}

Key words: Amides, amino benzylated Mannich bases, anthelmintic property, Pheritima posthuma, piperazine citrate

\section{INTRODUCTION}

Diseases caused by helminth parasites in livestock continue to be a major productivity constraint, especially small rhminants in the tropics and subtropics. Infections by gastrointestinal helminth parasites of livestock are among the most common and economically important diseases of grazing livestock. ${ }^{[1]}$ Various drugs used for the cure of helminth infections are triimidazoles, bithional, parabendazole, mebendazole, oxfendazole, niclosamide and piperazine etc. However, drugs like mebendazole have considerable side-effects such as mitotic arrest and

\begin{tabular}{|l|l|}
\hline \multicolumn{2}{|c|}{ Access this article online } \\
\hline Quick Response Code: & \\
\hline & Website: \\
\hline & www.jyoungpharm.in \\
& \\
\hline & DOI: \\
\hline
\end{tabular}

Journal of Young Pharmacists Vol 3 / No 3 apotosis etc., and the benzimidazole, imidazothiazole and macrocyclic lactones' class of drugs have become a global phenomenon in gastrointestinal nematodes of farm animals, hence there is a need for an anthelmintic with lesser side-effects. Also, due to escalating costs of research and development and limited commercial attractiveness, investment in research for new drug development for tropical diseases is much less as compared to other diseases.

It is well documented in the literature that Mannich bases are known to possess pharmacologically proven therapeutic potentials ${ }^{[2]}$ and they find application as antimicrobial, ${ }^{[3]}$ antitubercular, ${ }^{[4]}$ antimalarial, ${ }^{[5]}$ anticancer ${ }^{[6]}$ and local anesthetic drugs. ${ }^{[7]}$ Though extensive research work has been reported on Mannich bases, relatively very little is known so far about aminobenzylated Mannich bases ${ }^{[8,9]}$ of $\mathrm{N}$-methyl piperazine and the literature review revealed that piperazine and related compounds are known to possess anthelmintic activity. ${ }^{[10]}$ This enthused us to evaluate some 
of the synthesized ${ }^{[11-14]}$ aminobenzylated Mannich bases [Figure 1] for anthelmintic property in the present study.

Anthelmintic activity of the synthesized compounds

The study of anthelmintic activity was carried out according to the method of Ajaigeoba ${ }^{[15]}$ using Indian earth worm Pheritima posthuma due to its anatomical and physiological resemblance with the intestinal round worm parasites of human beings. ${ }^{[16,17]}$ Pheritima posthuma of nearly equal size $(8 \pm 1 \mathrm{~cm})$ were collected from waterlogged areas of fort lake in Mandya district, Karnataka, India for the present study.

\section{MATERIALS AND METHODS}

Preparation of sample solutions

The suspensions of the sample ${ }^{[18]}(0.1 \% \mathrm{w} / \mathrm{v}, 0.2 \% \mathrm{w} / \mathrm{v}$ and $0.3 \% \mathrm{w} / \mathrm{v}$ ) were prepared by triturating the compounds with distilled water and $0.5 \% \mathrm{w} / \mathrm{v}$ tween 80 and further transferred to a beaker labeled as $0.1 \%, 0.2 \%$ and $0.3 \%$ respectively, stirred for about $30 \mathrm{~min}$ at room temperature. The resulting solutions were then used for anthelmintic studies.

\section{Method of testing}

Fifty-five groups of approximately equal-sized $(8 \pm 1 \mathrm{~cm})$ Indian earthworms Pheritima posthama consisting of six earthworms in each group were placed in Petri dishes (4" size) containing suspensions of specific concentration $(0.1 \%, 0.2 \%, 0.3 \% \mathrm{w} / \mathrm{v})$ at room temperature. Each group was treated with one of the following: control $(0.5 \% \mathrm{w} / \mathrm{v}$ tween 80 in normal saline), piperazine citrate $(0.1 \%, 0.2 \%$, $0.3 \% \mathrm{w} / \mathrm{v}$ in normal saline) different concentration of compounds $(0.1 \%, 0.2 \%, 0.3 \%)$ respectively.

The times taken for complete paralysis and death were recorded using a stopwatch. The mean paralysis time and mean lethal time for each sample was recorded (each

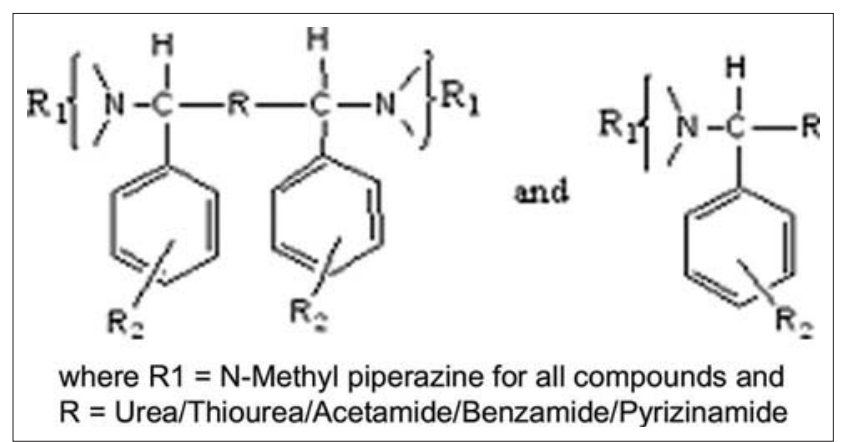

Figure 1: Schematic representation of compounds (e-h, 1e-1h, 2d-2f, 3e-3h) reading was taken in triplicate). The time taken by worms to become motionless was noted as paralysis time and to

Table 1: Anthelmintic activity of compounds (e-h, 1e1h, 2d-2f, 3e-3h)

\begin{tabular}{|c|c|c|c|}
\hline \multirow[t]{2}{*}{ Test compound } & \multirow[t]{2}{*}{$\%$ Concentration } & \multicolumn{2}{|c|}{ Time in minutes } \\
\hline & & For paralysis & For death \\
\hline Control (Normal saline) & 0.9 & - & - \\
\hline \multirow[t]{3}{*}{ Piperazine citrate(Std) } & 0.1 & 52 & 80 \\
\hline & 0.2 & 43 & 75 \\
\hline & 0.3 & 35 & 66 \\
\hline $\mathrm{e}$ & 0.1 & 94 & 130 \\
\hline $\mathrm{R}=-\mathrm{NHCONH}-$ & 0.2 & 82 & 121 \\
\hline $\mathrm{R}_{2}=\mathrm{P}-\mathrm{N}\left(\mathrm{CH}_{3}\right)_{2}$ & 0.3 & 70 & 109 \\
\hline $\mathrm{f}$ & 0.1 & 99 & 129 \\
\hline $\mathrm{R}=-\mathrm{NHCSNH}-$ & 0.2 & 91 & 120 \\
\hline $\mathrm{R}_{2}=\mathrm{P}-\mathrm{N}\left(\mathrm{CH}_{3}\right)_{2}$ & 0.3 & 83 & 107 \\
\hline g & 0.1 & 91 & 131 \\
\hline $\mathrm{R}=-\mathrm{NHCOCH}_{3}$ & 0.2 & 83 & 118 \\
\hline $\mathrm{R}_{2}=\mathrm{P}-\mathrm{N}\left(\mathrm{CH}_{3}\right)_{2}$ & 0.3 & 78 & 105 \\
\hline $\mathrm{h}$ & 0.1 & 102 & 142 \\
\hline $\mathrm{R}=-\mathrm{NHCOC}_{6} \mathrm{H}_{5}$ & 0.2 & 96 & 131 \\
\hline $\mathrm{R}_{2}=\mathrm{P}-\mathrm{N}\left(\mathrm{CH}_{3}\right)_{2}$ & 0.3 & 84 & 119 \\
\hline $1 \mathrm{e}$ & 0.1 & 86 & 135 \\
\hline $\mathrm{R}=\mathrm{NHCONH}-$ & 0.2 & 79 & 129 \\
\hline $\mathrm{R}_{2}=\mathrm{H}$ & 0.3 & 68 & 105 \\
\hline 1f & 0.1 & 79 & 125 \\
\hline \multirow{2}{*}{\multicolumn{4}{|c|}{$\mathrm{R}=-\stackrel{\mathrm{H}}{\mathrm{N}}-\stackrel{\mathrm{C}}{\mathrm{C}}-\mathrm{H}-\mathrm{N}-$}} \\
\hline & & & \\
\hline $\mathrm{R}=\mathrm{H}$ & 0.3 & 61 & 100 \\
\hline $1 \mathrm{~g}$ & 0.1 & 68 & 110 \\
\hline $\mathrm{R}=\mathrm{NHCOCH}_{3}$ & 0.2 & 53 & 99 \\
\hline $\mathrm{R}_{2}=\mathrm{H}$ & 0.3 & 49 & 87 \\
\hline $1 \mathrm{~h}$ & 0.1 & 72 & 121 \\
\hline $\mathrm{R}=-\mathrm{NHCOC}_{6} \mathrm{H}_{5}$ & 0.2 & 63 & 115 \\
\hline $\mathrm{R}_{2}=\mathrm{H}$ & 0.3 & 56 & 104 \\
\hline $2 \mathrm{~d}$ & 0.1 & 98 & 142 \\
\hline $\mathrm{R}=-\mathrm{NHCOC}_{4} \mathrm{H}_{3} \mathrm{~N}_{2}$ & 0.2 & 91 & 129 \\
\hline $\mathrm{R}_{2}=\mathrm{H}$ & 0.3 & 84 & 120 \\
\hline $2 \mathrm{e}$ & 0.1 & 115 & 161 \\
\hline $\mathrm{R}=-\mathrm{NH} \mathrm{COC} \mathrm{H}_{3} \mathrm{~N}_{2}$ & 0.2 & 108 & 154 \\
\hline $\mathrm{R}_{2}=2,5$-Dimethoxy & 0.3 & 97 & 139 \\
\hline $2 \mathrm{f}$ & 0.1 & 111 & 150 \\
\hline $\mathrm{R}=-\mathrm{NH} \mathrm{COC} \mathrm{H}_{3} \mathrm{~N}_{2}$ & 0.2 & 102 & 141 \\
\hline $\mathrm{R}_{2}=4-\mathrm{OH}$ & 0.3 & 93 & 130 \\
\hline $3 e$ & 0.1 & 110 & 159 \\
\hline $\mathrm{R}=-\mathrm{NHCONH}-$ & 0.2 & 105 & 145 \\
\hline $\mathrm{R}_{2}=3-\mathrm{NO}_{2}$ & 0.3 & 97 & 132 \\
\hline $3 \mathrm{f}$ & 0.1 & 106 & 152 \\
\hline & 0.2 & 95 & 144 \\
\hline \multicolumn{4}{|l|}{$\mathrm{R}=-\mathrm{H}-\mathrm{N}-\mathrm{C}-\mathrm{H}-$} \\
\hline $\mathrm{R}_{2}=3-\mathrm{NO}_{2}$ & 0.3 & 83 & 130 \\
\hline $3 g$ & 0.1 & 119 & 169 \\
\hline $\mathrm{R}=-\mathrm{NHCOCH}_{3}$ & 0.2 & 112 & 154 \\
\hline $\mathrm{R}_{2}=3-\mathrm{NO}_{2}$ & 0.3 & 101 & 138 \\
\hline $3 \mathrm{~h}$ & 0.1 & 119 & 167 \\
\hline $\mathrm{R}=-\mathrm{NH} \mathrm{COC}{ }_{6} \mathrm{H}_{5}$ & 0.2 & 100 & 159 \\
\hline $\mathrm{R}_{2}=3-\mathrm{NO}_{2}$ & 0.3 & 91 & 148 \\
\hline
\end{tabular}


note the death time the earthworms frequently applied with external stimuli by transferring them to a beaker containing hot water in order to check its mortality. The anthelmintic activities of the tested compounds on Pheritima posthuma (earthworm) are indicated in Table 1.

\section{RESULTS AND DISCUSSION}

The results of the anthelmintic activity exhibited by title compound on Pheritima posthuma are shown in Table 1. A closer inspection of data from this table indicates that compound $1 \mathrm{~g}$ was found to possess markedly higher anthelmintic activity than other compounds compared with standard. But all the other compounds were found to possess an interestingly low level of anthelmintic activity, which is a noteworthy feature of the present study.

\section{ACKNOWLEDGMENT}

The authors would like to thank the Principal, Govt. College of Pharmacy, Bangalore, and Director and Principal, NGSM IPS, Mangalore for providing the facilities to carry out the research work.

\section{REFERENCES}

1. Monteiro AM, Wangagu SW, Kariuki DP, Baiu R, Jackson F, Mckellor QA. Pharmaceutical quality of anthelmintics sold in Kenya. Vet Rec 1998;142:396-8.

2. Pandeya SN, Lahshmi VS, Pandeya A. Biological activity of Mannich bases. Indian J Pharm Sci 2002;65:213-22.

3. Jamel AA, Syed Ali PM. Synthesis and biological activities of some new mannich bases of furfural. Indian J Heterocycl Chem 2006;16:197-8.

4. Joshi S, Koshala N, Tiwari P. In vitro study of some medicinally important Mannich bases derived from antitubercular agent. Bioorg Med Chem 2004;12:571-6.
5. Chipeleme A, Gut J, Rosenthal JP, Chibale K. Synthesis and biological evaluation of phenolic Mannich bases of benzaldehyde and (thio) semicarbazone derivatives against the cystiene protease falcipain- 2 and a chloroquine resistant strain of Plasmodium falciparum. Bioorg Med Chem 2007;15:273-82.

6. Shivarama Holla B, Veerendra B, Shivananda MK, Poojary B. Synthesis characterization and anticancer activity studies on some Mannich bases derived from 1,2,4-triazoles. Eur J Med Chem 2003;38:759-67.

7. Chaturvedi SC, Patnaik GK, Dhawan BN, Dixit VK. Local anaesthetic activity of some para substituted acetophenone Mannich bases. Indian J Pharmacol 1985;17:155-7.

8. Vasoya SL, Chovatia PT, Purohit DH, Joshi SH. Green chemistry approach to the synthesis of potentially bioactive aminobenzylated Mannich bases through active hydrogen compounds. J Serb Chem Soc 2005;70:1163-7.

9. Nimavat KS, Poput SL, Vasoya SL, Joshi HS. Synthesis and antimicrobial activity of some new aminobenzylated Mannich bases. J Indian Chem Soc 2003;80:711-3.

10. The Merck Index. An Encyclopedia of Drugs, Chemicals and Biologicals. $13^{\text {th }}$ ed. White House Station, New Jersey: Merck and Co. Inc.; 2001. p. 1337.

11. Chaluvaraju KC, Bhat KI. Synthesis and biological activity of some aminobenzylated Mannich bases of benzaldehyde. Chem Asian J 2009;21:4960-2.

12. Chaluvaraju KC, Bhat KI. Synthesis and In-vitro study of novel aminobenzylated Mannich bases as anti-bacterial agents. J Indian Counc Chem 2009;26:90-3.

13. Chaluvaraju KC, Bhat KI. Synthesis and antimicrobial activity of aminobenzylated Mannich bases of pyrazinamide. Int J Chem Tech Res 2009;2:1368-71.

14. Chaluvaraju KC, Bhat KI. Aminobenzylated Mannich bases of amides. J Chem Pharm Sci 2010;3:138-40.

15. Ajaiyeoba EO, Onocha PA, Olarenwaju OT. In-vitro anthelmintic properties of bucbnolzia coriaceae and Gynandropsis gynandra extract. Pharm Biol 2001;39:217-20.

16. Vidyarthi RD. A text book of Zology. New Delhi: Chand S Co.; 1967. p. 329-70.

17. Chatterjee KD. Parasitology and Helminohology. In: Guha R, editor. Calcutta: Sree Saraswaty Press Ltd.; 1967. p. 168-9.

18. Dhaneshwar SR, Khadikar PV, Katiyar JC, Dhawan BN, Chaturvedi SC. Synthesis and anthelmintic activity of some Mannich bases of mebendazole. Indian J Pharm Sci 1990;52:261-3.

Cite this article as: Chaluvaraju $\mathrm{KC}$, Bhat $\mathrm{KI}$. Studies on the anthelmintic property of aminobenzylated mannich bases. J Young Pharmacists 2011;3:243-5.

Source of Support: Nil, Conflict of Interest: None declared. 